\title{
Effect of zinc supplementation from inorganic and organic sources on growth and blood biochemical profile in crossbred calves*
}

\author{
G.P. Mandal' ${ }^{1}$, R.S. Dass ${ }^{1,4}$, A.K. Garg ${ }^{1}$, V.P. Varshney ${ }^{2}$ \\ and A.B. Mondal ${ }^{3}$ \\ ${ }^{I}$ Center of Advanced Studies in Animal Nutrition, \\ Mineral and Vitamin Nutrition Laboratory, \\ Indian Veterinary Resesarch Institute \\ Izatnagar - 243 122, India \\ ${ }^{2}$ Division of Physiology and Climatology, \\ ${ }^{3}$ Division of Animal Nutrition and Feed Technology, Central Avian Research Institute \\ Izatnagar - 243 122, India
}

(Received 19 February 2008; accepted 8 April 2008)

\section{ABSTRACT}

The effect of zinc supplementation from inorganic and organic sources on some physiological and biochemical profile was investigated in 15 male crossbred calves (age 14-15 months, liveweight $226.0 \pm 9.06 \mathrm{~kg}$ ) randomly divided into three groups of five animals in each. Animals in group I (control) were fed a basal diet comprised of wheat straw and concentrate mixture (33 mg Zn kg-1 diet) with out any supplemental $\mathrm{Zn}$, while those in group 2 and group 3 were given basal diet supplemented with $35 \mathrm{mg} \mathrm{Zn} \mathrm{kg}^{-1}$ feed from zinc sulphate and zinc propionate, respectively. All the animals were fed individually on these dietary treatments for a period of 180 days. Body weights of all the calves were recorded fortnightly. Blood samples were collected from all the animals at 0 day and subsequently at an interval of 30 days to estimate certain serum minerals, enzymes, vitamins and hormones. There was no significant difference in the body weight gain among different groups. Zinc intake in groups 2 and 3 was significantly $(\mathrm{P}<0.001)$ higher as compared to group 1 , but serum zinc and copper concentration did not differ among the groups. Mean activity of alkaline phosphatase, glutamate oxaloacetate transaminase, glutamate pyruvate transaminase and super oxide dismutase was also similar in control and $\mathrm{Zn}$ supplemented groups. Mean concentrations of different serum vitamins (retinol, B-carotene and $\alpha$-tocopherol) and hormones (triiodothyronine, thyroxin, insulin and testosterone) were not affected by zinc supplementation from inorganic and organic sources in crossbred calves. It may be concluded that

\footnotetext{
* Supported by AP Cess Scheme, ICAR, Krishi Bhawan, New Delhi, India

${ }^{4}$ Corresponding author: e mail: rsd@ivri.up.nic.in
} 
supplementation of zinc in the diet of crossbred calves was not effective in improving the growth rate and concentration of minerals, enzymes, vitamins and hormones in blood serum or plasma in crossbred calves, which may be due to relatively small dose of zinc (35 mg Zn kg${ }^{-1}$ diet) used in this study.

KEY WORDS: calves, zinc sulphate, zinc propionate, $\mathrm{T}_{3}, \mathrm{~T}_{4}$, serum enzymes, serum vitamins

\section{INTRODUCTION}

Zinc is essential to both animals and human beings and plays significant role in different enzyme systems needed in nucleic acid metabolism, protein synthesis and carbohydrate metabolism (Chester, 1997). Kegley and Silzeli (1999) observed increased average daily gain in calves supplemented with 25 or 360 $\mathrm{mg} \mathrm{Zn} \mathrm{kg}{ }^{-1}$ to the basal diet marginally deficient in $\mathrm{Zn}\left(21\right.$ or $33 \mathrm{mg} \mathrm{Zn} \mathrm{kg} \mathrm{g}^{-1}$ diet). Marginal deficiency of zinc in ruminants has been reported in many parts of the tropical countries including different geological regions of India and thus needs supplementation in their diet. Trace minerals are generally supplemented in the animal diet as inorganic salts. However, in recent years, chelated or organic minerals are being used as the bioavailability of these minerals is more than their inorganic counterparts (Spears, 1989). Lambs supplemented with zinc proteinate had higher $\mathrm{Zn}$ retention than lambs given a similar concentration of $\mathrm{Zn}$ from zinc oxide, an inorganic source (Lardy et al., 1992).

Literature is silent on comparative usefulness of zinc sulphate and zinc propionate (chelated) as source of supplementary zinc in the diet of ruminants. Therefore, the present study was undertaken to assess the need of $\mathrm{Zn}$ supplementation and comparative efficacy of zinc sulphate and zinc propionate as source of supplemental $\mathrm{Zn}$ in the diet of male growing crossbred calves based on growth performance and certain zinc dependent biochemical parameters.

\section{MATERIAL AND METHODS}

\section{Animals, management and feeding}

This study was conducted on 15 male crossbred calves of about 14-15 months of age and $226.0 \pm 9.06 \mathrm{~kg}$ mean body weight, divided into three groups of five animals in each on the basis of their body weight, following randomized block design. All the calves were kept in sheds with cemented floor and individual feeding arrangements. Deworming was done at start of experiment, and subsequently at regular interval. All the calves were vaccinated against foot and mouth and Haemorrhagic septicaemia (H.S.) diseases. Animals in group 1 (control) were 
fed wheat straw and concentrate mixture (basal diet, no supplemental $\mathrm{Zn}$ ) and in group 2 and group 3 basal diet was supplemented with $35 \mathrm{mg} \mathrm{Zn} \mathrm{kg}^{-1}$ diet through zinc sulphate and zinc propionate, respectively. Before conducting the experiment, all the animals were maintained for 30 days on a basal diet comprised of concentrate mixture (\%: maize 30 , soyabean meal 27 , wheat bran 40 , mineral mixture 2 and common salt 1) and wheat straw in the ratio of 50:50 to meet their nutrient requirement for $500 \mathrm{~g}$ body weight gain/day (NRC, 2001). After 30 days of adaptation, calves were fed their respective treatment diets for a period of 180 days. Aqueous solution of zinc sulphate $(10 \%$, AR grade, M/s S.D. Fine Chemicals, Bombay, India) was prepared and calculated amount $(\mathrm{ml})$ was mixed daily with weighed amount of concentrate mixture for individual calf in group 2. Zinc propionate, containing $27 \%$ zinc, commercially known as Kemitrace ${ }^{\mathrm{TM}}$ (M/s Kemin Nutritional Technologies Pvt. Ltd., India), was weighed as per the requirement of individual calf in group 3 and mixed with weighed amount of concentrate mixture for their feeding. The amount of zinc to be supplemented was revised at weekly interval depending upon the total dry mater intake of individual calf. Calves were individually fed weighed amounts of concentrate mixture at $09.00 \mathrm{~h}$ and wheat straw was provided after complete consumption of concentrate mixture. Clean drinking water, containing no detectable amount of $\mathrm{Zn}$, was offered twice daily. The animals were weighed at start and after every fifteen days, and accordingly the amount of required concentrate mixture for each calf was calculated, based on their body weights. Two $\mathrm{kg}$ of green fodder (maize/oats/berseem) was provided twice a week to all the calves to meet vitamin A requirement. Blood samples were collected from all the calves at start and subsequently at monthly interval from jugular vein in clean dry test tubes with or with out anticoagulant; serum and plasma were separated and stored at $-20^{\circ} \mathrm{C}$ for further analysis.

\section{Chemical analysis}

Feed samples were analysed for proximate principles (AOAC, 2000) and fibre fractions (Van Soest et al., 1991). The chemical composition of the feeds offered to the experimental calves is presented in Table 1 . The crude protein content in wheat straw (WS), concentrate mixture (CM) and total mixed ration (TMR) was 21.2, 4.14 and 13.01\%, respectively. The $\mathrm{Zn}$ content in TMR was $32.54 \mathrm{mg} \mathrm{kg}^{-1}$ diet, almost comparable to $35 \mathrm{mg} \mathrm{Zn}$ recommended by NRC (2001) for growing calves. Concentration of copper and zinc in feeds and serum were estimated in an air-acetylene flame using atomic absorption spectrophotometer (Model No. 4141, Electronic Corporation of India, Ltd., Hyderabad, India). Serum alkaline phosphatase (ALP) activity (Kind and King, 1954), serum glutatamate oxaloacetate transaminase (SGOT) and serum 
Table 1. Chemical composition (\% DM basis) of concentrate mixture, wheat straw and total ration fed to crossbred calves

\begin{tabular}{lccc}
\hline Nutrients & $\begin{array}{c}\text { Concentrate } \\
\text { mixture }\end{array}$ & $\begin{array}{c}\text { Wheat } \\
\text { straw }\end{array}$ & $\begin{array}{c}\text { Total mixed } \\
\text { ration }\end{array}$ \\
\hline Crude protein & 21.2 & 4.14 & 13.01 \\
Ether extract & 1.73 & 0.81 & 1.29 \\
Neutral detergent fibre & 40.54 & 80.28 & 59.65 \\
Acid detergent fibre & 10.27 & 48.13 & 28.47 \\
Total ash & 8.26 & 7.96 & 8.12 \\
Acid insoluble ash & 1.74 & 4.57 & 3.10 \\
Zinc, mg kg & 52.84 & 10.62 & 32.54 \\
Copper, mg kg-1 & 28.15 & 5.66 & 16.90 \\
Iron, mg kg-1 & 556.36 & 738.46 & 647.41 \\
Manganese, mg kg-1 & 60.13 & 34.73 & 47.43 \\
\hline
\end{tabular}

${ }^{1}$ total mixed ration consisted of concentrate mixture and wheat straw in 1.08: 1.00 ratio

glutamate pyruvate transaminase (SGPT) activities (Reitman and Frankel, 1957) and erythrocyte super oxide dismutase (SOD) activity (Madesh and Balasubramaniam, 1998) were determined. Estimation of triiodothyronine $\left(\mathrm{T}_{3}\right)$, thyroxin $\left(\mathrm{T}_{4}\right)$, insulin and testosterone in blood plasma samples was done by radioimmunoassay technique using an automatic gamma counter (Packard, USA, Model Cobra II) by the method suggested by Bhandarkar and Pillai (1982). RIA kits for $\mathrm{T}_{3}$ and $\mathrm{T}_{4}$ were procured from M/s Immunotech Radiova (Czech Republic); testosterone kit from M/s Immunotech (France) and insulin kit from M/s Medicorp (Canada). Beta-carotene, retinol and $\alpha$-tocopherol in serum samples were estimated using high-performance liquid chromatography (HPLC; Schimadzu, Japan, Model SCL10 AVP, Version 5.03) as described by Chawla and Kaur (2001).

\section{Statistical analysis}

Data were statistically analysed using SPSS (1996) computer package. Generalized Linear Model ANOVA was used on growth performance data and Duncan's multiple range tests was used to conduct post hoc test. Repeated measures ANOVA was performed on blood minerals, enzymes, vitamins and hormones. GreenhouseGeisser adjusted significance test was applied to compare the values obtained in different months of experiment according to Little et al. (1998).

\section{RESULTS AND DISCUSSION}

The average daily gain (ADG, g/d) of the calves (Table 2 ) in groups 1, 2 and 3 was similar $(\mathrm{P}>0.05)$ without showing any effect of $\mathrm{Zn}$ supplementation. Similar 
findings were reported earlier (Malcolm-Callis et al., 2000; Huerta et al., 2002), where in no beneficial effect of supplemental zinc (18 to $220 \mathrm{mg} \mathrm{Zn} \mathrm{kg}^{-1}$ diet) to basal diets containing more than $20 \mathrm{mg} \mathrm{Zn} \mathrm{kg}^{-1}$ diet was observed on body weight gain. Contrary to above Spears (1989) indicated that Zn supplementation (25 $\mathrm{mg} \mathrm{Zn} \mathrm{kg}^{-1}$ diet) as zinc oxide or Zn-methionine to a basal diet with $23 \mathrm{mg}$ $\mathrm{Zn} \mathrm{kg}^{-1}$ diet improved body weight gain during first 56 days of the study; but

Table 2. Effect of zinc supplementation on body weight gain and serum zinc level in crossbred calves

\begin{tabular}{lcccc}
\hline \multirow{2}{*}{ Item } & \multicolumn{5}{c}{ Group } & SEM \\
\cline { 2 - 5 } & \multicolumn{2}{c}{2} & 226.6 & 8.95 \\
\hline Initial body weight, $\mathrm{kg}$ & 227.1 & 224.1 & 321.6 & 8.35 \\
Final body weight, $\mathrm{kg}$ & 317.2 & 311.0 & 528.0 & 9.12 \\
Body weight gain, $\mathrm{g} \mathrm{d}^{-1}$ & 501.0 & 484.0 & 5.26 & 0.167 \\
Dry matter intake, $\mathrm{kg} \mathrm{d}^{-1}$ & 5.20 & 4.88 & 10.07 & 0.398 \\
Feed:gain ratio & 10.42 & 10.11 & $373.0^{\mathrm{a}}$ & $29.21^{\star}$ \\
Zinc intake, $\mathrm{mg} \mathrm{d}^{-1}$ & $166.9^{\mathrm{b}}$ & $341.9^{\mathrm{a}}$ & 1.54 & 0.05 \\
Serum zinc, $\mathrm{mg} \mathrm{l}^{-1}$ & 1.55 & 1.52 & 95.6 & 3.61 \\
Copper intake, $\mathrm{mg} \mathrm{d}^{-1}$ & 95.9 & 89.7 & 1.02 & 0.03 \\
Serum copper, $\mathrm{mg} \mathrm{l}^{-1}$ & 1.01 & 1.10 & & \\
\hline
\end{tabular}

${ }^{*}$ means bearing different superscript in a row differ significantly $(\mathrm{P}<0.001)$

group 1: basal diet (32.5 mg Zn kg-1 diet); group 2: basal diet $+35 \mathrm{mg} \mathrm{Zn} \mathrm{kg}^{-1}$ diet as zinc sulphate; group 3: basal diet $+35 \mathrm{mg} \mathrm{Zn} \mathrm{kg}^{-1}$ diet as zinc propionate

failed to improve growth thereafter during 57 and 126 days of study. Similarly, Kegley and Silzeli (1999) reported improved weight gain in calves supplemented with $\mathrm{Zn}$ to a basal diet containing $21 \mathrm{mg} \mathrm{Zn} \mathrm{kg}^{-1}$ diet. In the present study, feed: gain ratio was also not affected by zinc supplementation from inorganic and organic $\mathrm{Zn}$ supplementation. The $\mathrm{Zn}$ intake in sulphate or propionate supplemented groups was higher $(\mathrm{P}<0.001)$ than control (Table 2$)$, but serum $\mathrm{Zn}$ levels did not differ $(\mathrm{P}>0.05)$ due to groups. Similarly, Spears et al. (2004) did not find any effect of organic $\mathrm{Zn}$ supplementation on plasma $\mathrm{Zn}$ concentration in steers. Contrary to this, Huerta et al. (2002) reported that the concentration of $\mathrm{Zn}$ in the serum of steers was affected by level of dietary $\mathrm{Zn}(\mathrm{P}<0.05)$ and duration of $\mathrm{Zn}$ feeding $(\mathrm{P}<0.01)$. Steers supplemented with $200 \mathrm{mg} \mathrm{Zn} \mathrm{kg}^{-1}$ diet had higher concentration of $\mathrm{Zn}$ in serum than steers fed control diet. They further reported that heifers fed the diet with $\mathrm{Zn}$-Meth had higher $(\mathrm{P}<0.05)$ concentration of $\mathrm{Zn}$ in serum than heifers fed the control or $\mathrm{Zn} \mathrm{SO}_{4}$ supplemented diets. Similarly, Salma Ahmad et al. (2003) did not find any change in serum $\mathrm{Zn}$ level in lactating goats supplemented with Zn-Meth in comparison to control group. Results revealed no significant effect on copper intake and copper serum level in three groups. Contrary to this, Salma Ahmad et al. (2003) observed higher serum copper level in lactating goats 
supplemented with Zn-Meth in comparison to inorganic $\mathrm{Zn}$ supplemented group. On the other hand, Huerta et al. (2002) observed depressed copper concentration in serum of steers, which were supplemented with $200 \mathrm{mg}$ of $\mathrm{Zn} \mathrm{kg}^{-1}$ diet. An antagonism of dietary $\mathrm{Zn}$ and $\mathrm{Cu}$ has been demonstrated in cattle (Wellington et al., 1998). No antagonistic effect of $\mathrm{Zn}$ supplementation on serum copper level was observed in this study, which may be due to low level of $\mathrm{Zn}$ supplementation.

The serum enzymes activities are presented in Table 3. The ALP activity was similar $(\mathrm{P}>0.05)$ due to $\mathrm{Zn}$ levels or sources but decreased with the advancement of age. Serum ALP is a $\mathrm{Zn}$ metalloenzyme that decreases in $\mathrm{Zn}$ deficiency and

Table 3. Effect of zinc supplementation on serum enzyme activity in crossbred calves

\begin{tabular}{|c|c|c|c|c|c|c|c|c|}
\hline \multirow{2}{*}{ Group } & \multicolumn{6}{|c|}{ Period, days } & \multirow{2}{*}{ Mean } & \multirow{2}{*}{ SEM } \\
\hline & 0 & 30 & 60 & 90 & 120 & 180 & & \\
\hline \multicolumn{9}{|c|}{$A L P, K A$ Unit } \\
\hline 1 & 30.8 & 26.0 & 24.5 & 20.0 & 19.7 & 20.2 & 23.6 & 1.12 \\
\hline 2 & 40.1 & 35.0 & 30.6 & 18.2 & 22.1 & 23.7 & 28.3 & 1.91 \\
\hline 3 & 27.9 & 24.3 & 24.4 & 19.5 & 20.2 & 28.4 & 24.1 & 1.24 \\
\hline \multicolumn{9}{|c|}{ SGOT, Unit/ml } \\
\hline 1 & 24.1 & 20.1 & 23.70 & 12.4 & 26.6 & 31.6 & 23.1 & 1.32 \\
\hline 2 & 20.5 & 19.7 & 25.7 & 13.6 & 26.2 & 29.4 & 22.5 & 1.08 \\
\hline 3 & 18.2 & 21.1 & 24.4 & 22.8 & 25.4 & 31.4 & 23.9 & 0.91 \\
\hline \multicolumn{9}{|c|}{ SGPT, Unit/ml } \\
\hline 1 & 18.6 & 13.9 & 17.9 & 21.7 & 21.5 & 18.3 & 18.6 & 0.88 \\
\hline 2 & 21.7 & 14.9 & 16.8 & 18.7 & 17.3 & 16.4 & 17.6 & 0.86 \\
\hline 3 & 22.3 & 14.6 & 17.0 & 16.3 & 20.5 & 17.9 & 18.1 & 0.67 \\
\hline \multicolumn{9}{|c|}{ SOD, mmol formazone formed/g haemoglobin } \\
\hline 1 & 5.06 & 5.71 & 5.84 & 3.61 & 4.17 & 5.80 & 5.03 & 0.36 \\
\hline 2 & 5.69 & 5.43 & 5.48 & 3.59 & 4.05 & 7.22 & 5.24 & 0.32 \\
\hline 3 & 5.01 & 5.88 & 4.17 & 4.01 & 5.69 & 6.65 & 5.24 & 0.31 \\
\hline
\end{tabular}

group 1: basal diet (32.5 $\mathrm{mg} \mathrm{Zn} \mathrm{kg}^{-1}$ diet); group 2: basal diet $+35 \mathrm{mg} \mathrm{Zn} \mathrm{kg}^{-1}$ diet as zinc sulphate; group 3: basal diet $+35 \mathrm{mg} \mathrm{Zn} \mathrm{kg}^{-1}$ diet as zinc propionate

ALP: alkaline phosphatase

SGOT: serum glutatamate oxaloacetate transaminase

SGPT: serum glutamate pyruvate transaminase

SOD: super oxide dismutase

serum ALP activity is used as an indictor of animal Zn status (Miller et al., 1965). Over the course of present study, zinc supplementation had no significant influence on the ALP activity. In contrary, Spears (1989) observed higher plasma ALP activity on $\mathrm{Zn}$ feeding (48.8 $\mathrm{mg} \mathrm{Zn} \mathrm{kg}^{-1}$ ) in heifers than control $(23.8 \mathrm{mg} \mathrm{Zn} \mathrm{kg}$ diet).Over the course of present study, Zn supplementation had no significant 
influence on the ALP activity. However, results in present study were supported by Hatfield et al. (2002) in ewes where ALP did not respond to additional Zn (84 vs $65 \mathrm{mg} \mathrm{Zn} \mathrm{kg}^{-1}$ diet). No changes $(\mathrm{P}>0.05)$ in SGOT, SGPT and erythrocyte SOD activities were observed due to $\mathrm{Zn}$ level, source or duration of feeding. Contrary to these findings, Daghash and Mousa (1999) observed higher SGOT and SGPT activity in buffalo calves supplemented with 50 or $100 \mathrm{ppm} \mathrm{Zn}$. The SOD, a Zn-metalloenzyme is considered important for protection of cellular membranes from super oxide radicals. Mean activity of SOD in different groups did not show any difference $(\mathrm{P}>0.05)$. Similar were the findings of Atreja et al.(1984) who also did not find any difference in blood SOD activity in goats fed diets having either with 15 or $80 \mathrm{ppm}$ of zinc for 36 weeks.

The mean concentration of serum $\beta$-carotene $(\mu \mathrm{g} / \mathrm{ml})$ ranged from 0.65 to 0.96 and exhibited non-significant $(\mathrm{P}>0.05)$ variation among dietary treatments (Table 4). Similarly, Jadhav (2005) did not find any effect of different levels of

Table 4. Effect of zinc supplementation on serum vitamin concentration in calves

\begin{tabular}{|c|c|c|c|c|c|c|c|c|}
\hline \multirow{2}{*}{ Group } & \multicolumn{6}{|c|}{ Period, days } & \multirow{2}{*}{ Mean } & \multirow{2}{*}{ SEM } \\
\hline & 0 & 30 & 60 & 90 & 120 & 180 & & \\
\hline \multicolumn{9}{|c|}{$\beta$-carotene, $\mu \mathrm{g} / \mathrm{ml}$} \\
\hline 1 & 1.06 & 1.23 & 0.77 & 1.09 & 0.88 & 0.52 & 0.78 & 1.32 \\
\hline 2 & 1.19 & 1.69 & 1.17 & 0.86 & 0.83 & 0.31 & 0.65 & 1.08 \\
\hline 3 & 1.28 & 0.96 & 0.48 & 1.05 & 0.58 & 0.37 & 0.65 & 0.91 \\
\hline \multicolumn{9}{|c|}{ Retinol, $\mu \mathrm{g} / \mathrm{ml}$} \\
\hline 1 & 1.42 & 1.47 & 1.15 & 0.97 & 0.65 & 0.95 & 0.11 & 0.88 \\
\hline 2 & 1.27 & 1.32 & 0.78 & 0.65 & 0.63 & 0.80 & 0.07 & 0.86 \\
\hline 3 & 1.18 & 0.98 & 0.48 & 1.09 & 0.56 & 0.85 & 0.07 & 0.67 \\
\hline \multicolumn{9}{|c|}{$\alpha$-tocopherol, $\mu \mathrm{g} / \mathrm{ml}$} \\
\hline 1 & 1.06 & 1.01 & 0.98 & 0.77 & 0.81 & 0.91 & 0.06 & 0.06 \\
\hline 2 & 0.99 & 0.99 & 0.88 & 0.84 & 1.12 & 1.01 & 0.08 & 0.08 \\
\hline 3 & 0.96 & 0.87 & 0.97 & 1.15 & 1.06 & 1.03 & 0.06 & 0.06 \\
\hline
\end{tabular}

group I: basal diet (32.5 mg Zn kg-1 diet); group II: basal diet $+35 \mathrm{mg} \mathrm{Zn} \mathrm{kg}^{-1}$ diet as zinc sulphate; group III: basal diet $+35 \mathrm{mg} \mathrm{Zn} \mathrm{kg}^{-1}$ diet as zinc propionate

$\mathrm{Zn}$ supplementation on $\beta$-carotene level in blood serum of buffalo calves. The mean serum retinol and $\alpha$-tocopherol concentrations $(\mu \mathrm{g} / \mathrm{ml})$ were also similar $(\mathrm{P}>0.05)$ in control and treatment groups. Zinc is required to maintain normal plasma retinol concentration (Chhabra and Arora,1985), however, the level or source (sulphate or propionate) of $\mathrm{Zn}$ did not influence serum retinol concentration. The present findings were contradictory to earlier observation in buffalo calves (Daghash and Mousa,1999). It appeared in present study 
that $33 \mathrm{mg} \mathrm{Zn} \mathrm{kg}{ }^{-1}$ diet was enough to maintain normal retinol levels. Kim et al. (1998) reported that intestinal absorption of vitamin E was affected by Zn status of rats. However, in the present study no such effect was observed as serum a-tocopherol levels remained similar in all the three groups. Hatfield et al. (2002) also did not find any effect on serum $\alpha$-tocopherol concentration in ewes fed either with 149 or $84.4 \mathrm{mg} \mathrm{Zn} \mathrm{kg}^{-1}$ diet.

The mean concentrations of plasma $\mathrm{T}_{3}, \mathrm{~T}_{4}(\mathrm{nmol} / \mathrm{l})$, insulin $(\mathrm{pmol} / \mathrm{ml})$ and testosterone $(\mathrm{ng} / \mathrm{ml})$ hormones were comparable $(\mathrm{P}>0.05)$ in three groups (Table $5)$. It indicated that supplemental zinc either from inorganic or organic sources did not influence plasma $\mathrm{T}_{3}$ and $\mathrm{T}_{4}$ concentration in crossbred calves. Contrary to above Kececi and Keskin (2002) in lambs observed reduced concentration of serum $\mathrm{T}_{3}$ and $\mathrm{T}_{4}$ on supplementation of $290 \mathrm{mg} \mathrm{Zn} \mathrm{kg}^{-1}$ diet. The mean concentration of plasma insulin exhibited non-significant $(\mathrm{P}>0.05)$ variation among dietary treatments. Similar observations were made by Engle et al. (1997) who also did not find any effect on plasma insulin concentration in relation to $\mathrm{Zn}$ supplementation in beef calves. Zinc is known to influence testosterone synthesis by virtue of its role in stimulation of Ledig cells of testis (Fang and

Table 5. Effect of zinc supplementation on plasma hormones level in crossbred calves

\begin{tabular}{|c|c|c|c|c|c|c|c|c|c|}
\hline \multirow{2}{*}{ Group } & \multicolumn{7}{|c|}{ Period, days } & \multirow{2}{*}{ Mean } & \multirow{2}{*}{ SEM } \\
\hline & 0 & 30 & 60 & 90 & 120 & 150 & 180 & & \\
\hline \multicolumn{10}{|c|}{$T_{3,} \mathrm{nmol} / \mathrm{l}$} \\
\hline 1 & 2.03 & 2.80 & 2.66 & 2.28 & 2.35 & 1.78 & 1.90 & 2.29 & 0.14 \\
\hline 2 & 2.29 & 2.32 & 2.55 & 1.90 & 2.08 & 1.61 & 1.59 & 2.05 & 0.09 \\
\hline 3 & 2.18 & 2.59 & 2.77 & 2.07 & 2.33 & 1.99 & 2.04 & 2.25 & 0.08 \\
\hline \multicolumn{10}{|c|}{$T_{4}, \mathrm{nmol} / \mathrm{l}$} \\
\hline 1 & 70.6 & 79.9 & 87.7 & 75.3 & 84.6 & 66.6 & 59.3 & 74.9 & 4.93 \\
\hline 2 & 79.2 & 65.4 & 77.0 & 65.2 & 80.1 & 51.41 & 59.7 & 68.3 & 3.01 \\
\hline 3 & 83.5 & 87.3 & 92.9 & 79.3 & 87.3 & 64.9 & 63.2 & 79.8 & 3.64 \\
\hline \multicolumn{10}{|c|}{ Insulin, pmol/l } \\
\hline 1 & 273.6 & 279.0 & 283.4 & 340.1 & 386.3 & 297.3 & 338.8 & 314.1 & 12.3 \\
\hline 2 & 242.9 & 261.1 & 301.0 & 409.7 & 333.9 & 425.2 & 353.5 & 332.5 & 18.4 \\
\hline 3 & 245.7 & 296.0 & 314.8 & 402.3 & 389.8 & 418.2 & 345.5 & 344.6 & 12.0 \\
\hline \multicolumn{10}{|c|}{ Testosterone, $\mathrm{ng} / \mathrm{ml}$} \\
\hline 1 & 3.48 & 3.69 & 3.05 & 2.94 & 1.08 & 2.79 & 1.36 & 2.63 & 0.34 \\
\hline 2 & 5.22 & 3.61 & 2.90 & 2.09 & 1.52 & 2.37 & 1.17 & 2.70 & 0.36 \\
\hline 3 & 4.00 & 2.22 & 1.56 & 1.09 & 2.91 & 1.27 & 1.90 & 2.14 & 0.27 \\
\hline
\end{tabular}

group 1: basal diet (32.5 mg Zn kg-1 diet); group 2: basal diet $+35 \mathrm{mg} \mathrm{Zn} \mathrm{kg}^{-1}$ diet as zinc sulphate; group 3: basal diet $+35 \mathrm{mg} \mathrm{Zn} \mathrm{kg}^{-1}$ diet as zinc propionate

$\mathrm{T}_{3}$ : triiodothyronine

$\mathrm{T}_{4}$ : thyroxin 
Furuhasi, 1978) and also as a structural component of proteins responsible in the synthesis, secretion and transport of testosterone. In the present experiment, plasma testosterone level was unaffected by zinc supplementation, which was also supported by Tharwat (1998), who did not observe any difference in serum testosterone level due to Zn supplementation in diet of rabbits. In contrary, El-Masry et al. (1994) reported increased serum testosterone levels on $\mathrm{Zn}$ supplementation in diets of rabbits.

\section{CONCLUSIONS}

It may be concluded that supplementation of zinc in the diet of crossbred calves was not effective in improving the growth rate and concentration of minerals, enzymes, vitamins and hormones in blood serum or plasma in crossbred calves, which may be due to relatively small dose of zinc ( $35 \mathrm{mg} \mathrm{Zn} \mathrm{kg}^{-1}$ diet) used in this study.

\section{ACKNOWLEDGEMENTS}

First author is thankful to Indian Council of Agricultural Research, Krishi Bhawan, New Delhi, for providing financial assistance in the form of Senior Research Fellowship. We are thankful to M/s Kemin Nutritional Technologies (India) Pvt. Ltd., Gummidipundi-601201, Tamil Nadu, India, for providing a gift sample of zinc propionate for this study.

\section{REFERENCES}

AOAC, 2000. Association of Official Analytical Chemists, Official Methods of Analysis. $16^{\text {th }}$ Edition. Washington, DC

Atreja P. P., Chhabra A., Arora S.P., Prasad T., 1984. Influence of level of zinc nutrition on zinc uptake and blood superoxide dismutase activity in ruminants. Indian J. Anim. Nutr. 1, 69-72

Bhandarkar S.D., Pillai M.I.A., 1982. Radioimmunoassay: A Laboratory Manual. Bhabha Atomic Research Centre, Trombay, Bombay (India)

Chawla R., Kaur H., 2001. Isocratic HPLC method for simultaneous determination of $\beta$-carotene, retinol and $\alpha$-tocopherol in feeds and blood plasma. Indian J. Dairy Sci. 54, 84-90

Chester J.K., 1997. Zinc. In: B.L. O’Dell, R. Sunde (Editors). Handbook of Nutritionally Essential Mineral Elements. Marcel Dekker Inc., New York, pp. 185

Chhabra A., Arora S.P., 1985. Effect of Zn deficiency on serum vitamin A level, tissue enzymes and histological alterations in goats. Livest. Prod. Sci. 12, 69-77

Daghash H.A., Mousa S.M., 1999. Zinc sulfate supplementation to ruminant rations and its effects on digestibility in lamb; growth, rectal temperature and some blood constituents in buffalo calves under heat stress. Assiut Vet. Med. J. 40, 128-146

El-Masry K.A., Nasr A.S., Kamal T.H., 1994. Influence of season and dietary supplementation with selenium and vitamin E or zinc on some blood constituents and semen quality of New Zealand White rabbit males. World Rabbit Sci. 2, 79-86 
Engle T.E., Nockels C.F., Hossener K.L., Kimberling C.V., Toombs R.E., Yemm R.S., Weaber D.L., Johnson A.B., 1997. Marginal zinc deficiency affects biochemical and physiological parameters in beef heifer calves. Asian-Austr. J. Anim. Sci. 10, 471-477

Fang V.S., Furuhasi N., 1978. Partial alleviation of the antitesticular effect of pipecolinomethylhydroxy indane by zinc in rats. J. Endocrinol. 79, 151

Hatfield P.G., Robinson B.L., Minikhiem D.L., Kott R.W., Roth N.I., Daniels J.T., Swenson C.K., 2002. Serum $\alpha$-tocopherol and immune function in yearling ewes supplemented with zinc and vitamin E. J. Anim. Sci. 80, 1329-1334

Huerta M., Kincid R.L., Cronrach J.D., Busboom J., Johnson A.B., Swenson C.K., 2002. Interaction of dietary zinc and growth implants on weight gain, carcass traits and zinc in tissues of growing beef steers and heifers. Anim. Feed Sci. Tech. 95, 15-32

Jadhav Sunil Eknath, 2005. Effect of different levels and sources of zinc supplementation on growth, nutrient utilization, rumen fermentation, blood biochemical and immune response in male buffalo calves. PhD. Thesis, Indian Veterinary Research Institute, Izatnagar (India)

Kececi T., Keskin E., 2002. Zinc supplementation decrease total thyroid hormone concentration in small ruminants. Acta Vet. Hung. 50, 93-100

Kegley B., Silzeli S., 1999. The immune response and performance of calves supplemented with zinc from an organic and an inorganic source. Res. Ser. Arkansas Agr. Exp. Sta. 460, 98-101

Kim Eul-sang, Noh S.K., Koo S.I., 1998. Marginal zinc deficiency lowers the lymphatic absorption of $\alpha$-tocopherol in rats. J. Nutr. 128, 265-270

Kind P.R., King E.J., 1954. Estimation of plasma phosphatase by determination of hydrolyzed phenol with amino-antipyrine. J. Clin. Pathol. 7, 322-326

Lardy G.P., Kerley M.S., Patterson J.A., 1992. Retention of chelated metal proteinates by lambs. J. Anim. Sci. 70, Suppl., 314 (Abstr.)

Little R.C., Henry P.R., Ammerman C.B., 1998. Statistical analysis of repeated measures data using SAS procedures. J. Anim. Sci. 76, 1216-1231

Madesh M., Balasubramaniam K.A., 1998. Micro titer plate assay for superoxide dismutase using MTT reduction by superoxide. Indian J. Biochem. Biophys. 35, 184-188

Malcolm-Callis K.J., Duff G.C., Gunter S.A., Kegley E.B., Vermeire D.A., 2000. Effects of supplemental zinc concentration and source on performance, carcass characteristics and serum values in finishing beef steers. J. Anim. Sci. 78, 2801-2808

Miller W.J., Pitts W.J., Clifton C.M., Morton J.D., 1965. Effects of zinc deficiency per se on feed efficiency, serum alkaline phosphatase, zinc in skin, behavior, greying, and other measurements in the Holstein calf. J. Dairy Sci. 48, 1329-1334

NRC, 2001. Nutrient Requirements of Dairy Cattle. National Academy of Science. Washington, DC

Reitman S., Frankel S.E., 1957. A colorimetric method for the determination of serum glutamic oxaloacetic transaminase and serum glutamic pyruvic transaminase. Amer. J. Clin. Pathol. 28, 56-63

Salama Ahmad A.K., Cajat G., Albanell E., Snch X., Casals R., 2003. Effects of dietary supplements of zinc-methionine on milk production, udder health and zinc metabolism in dairy goats. J. Dairy Res. 70, 9-17

Spears J.W., 1989. Zinc methionine for ruminants: Relative bioavailability of zinc in lambs and effect on growth and performance of growing heifers. J. Anim. Sci. 67, 835-843

Spears J.W., Schegel P., Seal M.C., Lloyd K.E., 2004. Bioavailability of zinc from zinc sulphate and different zinc sources and their effects on ruminal volatile fatty acid proportions. Livest. Prod. Sci. 90, 211-217

SPSS, 1996. Statistical Packages for Social Sciences, Version 7.5, SPSS Inc. Illinois (USA)

Tharwat E.E., 1998. The use of zinc sulphate to improve semen characteristics and fertility of New Zealand White rabbit buck during hot season. Ann. Agr. Sci. (Cairo) 3, 75-77

Van Soest P.J., Robertson J.B., Lewis B.A., 1991. Methods of dietary fiber, neutral detergent fiber and non-starch polysaccharides in relation to animal nutrition. J. Dairy Sci. 74, 3583-3587

Wellington B.K., Patterson J.A., Swenson C .K., Ansotegui R.P., Hatfield P.G., Johnson B., 1998. The influence of supplemental copper and zinc on beef heifer performance and changes in liver copper. Proc. West. Sect. Amer. Soc. Anim. Sci. 49, 323-326 